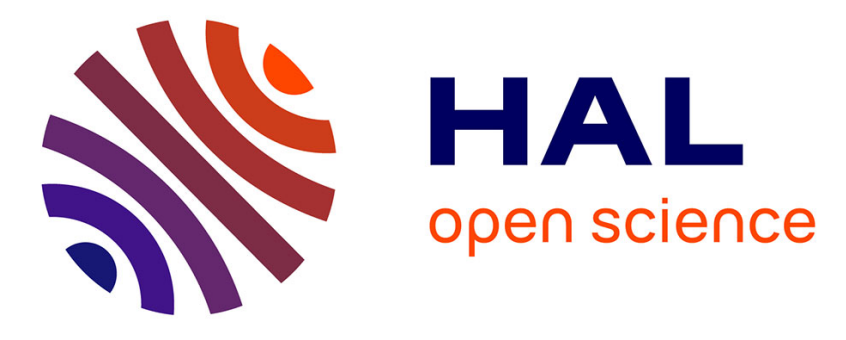

\title{
In search of consensus: Terminology for entheseal changes (EC)
}

Sébastien Villotte, Sandra Assis, Francisca Alves Cardoso, Charlotte Yvette

Henderson, Valentina Mariotti, Marco Milella, Doris Pany-Kucera, Nivien

Speith, Cynthia Wilczak, Robert Jurmain

\section{To cite this version:}

Sébastien Villotte, Sandra Assis, Francisca Alves Cardoso, Charlotte Yvette Henderson, Valentina Mariotti, et al.. In search of consensus: Terminology for entheseal changes (EC). International Journal of Paleopathology, 2016, 13, pp.49-55. 10.1016/j.ijpp.2016.01.003 . hal-02266502

\section{HAL Id: hal-02266502 https://hal.science/hal-02266502}

Submitted on 19 Feb 2021

HAL is a multi-disciplinary open access archive for the deposit and dissemination of scientific research documents, whether they are published or not. The documents may come from teaching and research institutions in France or abroad, or from public or private research centers.
L'archive ouverte pluridisciplinaire HAL, est destinée au dépôt et à la diffusion de documents scientifiques de niveau recherche, publiés ou non, émanant des établissements d'enseignement et de recherche français ou étrangers, des laboratoires publics ou privés. 


\section{TECHNICAL NOTE}

Title: In Search of Consensus: Terminology for Entheseal Changes (EC)

Short title: Terminology for EC

Authors and Affiliations:

\section{Sébastien Villotte}

Anthropologie des Populations Passées et Présentes, UMR 5199 PACEA, Bâtiment B8, Allée Geoffroy Saint Hilaire, Université de Bordeaux, CS, 50023, Pessac Cedex, France 33615

s.villotte@pacea.u-bordeaux1.fr

\section{Sandra Assis}

CIAS - Research Centre for Anthropology and Health, Department of Life Sciences, University of Coimbra, Portugal.

sandraassis78@gmail.com

Francisca Alves Cardoso

NOVA CRIA - Centre for Research in Anthropology, Faculty of Social Sciences and Humanities, Universidade NOVA de Lisboa, Portugal.

francicard@fcsh.unl.pt

Charlotte Yvette Henderson

CIAS - Research Centre for Anthropology and Health, Department of Life Sciences, University of Coimbra, Portugal.

c.y.henderson@uc.pt

Valentina Mariotti

1-Laboratorio di Bioarcheologia ed Osteologia Forense - Antropologia - Dipartimento di Scienze Biologiche, Geologiche e Ambientali - Alma Mater Studiorum Università di Bologna,Via Selmi 3, 40126 Bologna.

2- ADÉS, UMR 7268 CNRS/Aix-Marseille Université/EFS, Aix-Marseille Université, CS80011, Bd Pierre Dramard, 13344 Marseille Cedex 15 (France).

valentina.mariotti@unibo.it

\section{Marco Milella}

Anthropological Institute \& Museum, University of Zurich, Winterthurerstrasse 190, 8057 Zurich, Switzerland. marco.milella@aim.uzh.ch

Doris Pany-Kucera

Natural History Museum Vienna, Department of Anthropology/Institute for Oriental and European Archaeology, Austrian Academy of Sciences, Vienna, Austria 
dpany@nhm-wien.ac.at

\author{
Nivien Speith \\ Fern Barrow, Poole BH12 5BB, UK \\ nspeith@bournemouth.ac.uk \\ Cynthia A Wilczak \\ Department of Anthropology, San Francisco State University, San Francisco, CA USA \\ cwilczak@sfsu.edu \\ Robert Jurmain \\ Department of Anthropology, San Jose State University, San Jose, CA USA \\ robert.jurmain@sjsu.edu
}

Department of Archaeology, Anthropology and Forensic Science, Bournemouth University, Talbot Campus,

Corresponding author:

Sébastien Villotte,

Anthropologie des Populations Passées et Présentes, UMR 5199 PACEA, Bâtiment B8, Allée Geoffroy Saint Hilaire, Université de Bordeaux, CS, 50023, Pessac Cedex, France 33615

\begin{abstract}
This article presents a consensus terminology for entheseal changes that was developed in English by an international team of scholars and then translated into French, Italian, Portuguese, Spanish and German. Use of a standard, neutral terminology to describe entheseal morphology will reduce misunderstandings between researchers, improve the reliability of comparisons between studies, and eliminate unwarranted etiological assumptions inherent in some of the descriptive terms presently used in the literature.
\end{abstract}

Keywords: Enthesis; terminology; Fibrocartilaginous enthesis; spondyloarthropathies; diffuse idiopathic skeletal hyperostosis (DISH)

\author{
Abbreviations: \\ Entheseal change: EC \\ Fibrocartilaginous enthesis: FCE
}

\section{Introduction}

"Musculoskeletal stress markers", renamed "entheseal changes" (ECs) by Jurmain and Villotte (2010), have been widely studied in past populations as indicators of activity and social divisions of labor (e.g. Dutour, 1986; Hawkey and Merbs, 1995; Robb, 1998; Villotte et al., 2010a; Havelková et al., 2011, 2013; Lieverse et al., 2013; 
Villotte and Knüsel, 2014). However, the problem of oversimplified etiological interpretations that primarily equated EC with increased muscle use became widely apparent at a workshop held in 2009 in Coimbra, Portugal (Santos et al., 2011). Discussions at this meeting led to the establishment of three working groups aimed at standardizing key EC research aspects, namely terminology, recording methodology, and the understanding of definitions of occupation. The three working groups met again in Coimbra at a new workshop in 2013.

This technical note focuses on the results from the terminology working group (SV, RJ). A survey of researchers taken prior to the 2013 workshop clearly showed the need for standardized descriptions of ECs. Only one third of respondents described the EC in Figure 1c using the same term (Table 1), and a similar lack of consensus was found for other types of ECs. During the 2013 workshop, the terminology working group compiled an initial list of neutral terms and descriptions of the most common EC types. The terms proposed by this group have been discussed with the members of the other working groups (SA, FAC, CYH, VM, MM, DPK, NS, CAW), and a consensus was finally reached. The terminology proposed here includes neutral (i.e. without inherent etiological concepts), descriptive terms with figures (Fig. 1 and 2, see also Table 2 for other illustrations of the EC defined here in previous publications by the authors), which researchers can use to describe ECs arising from any etiology, including those associated with pathological conditions, e.g. the seronegative spondyloarthropathies or diffuse idiopathic skeletal hyperostosis. It should be noted that similar changes can occur at other anatomical locations (e.g. synovial joints), but this is outside the scope of this paper. The proposed terminology (Fig. 3), alongside its translation into five major European languages (Table 2), should reduce communication barriers as well as lead to improved data sharing amongst researchers if widely adopted.

\section{TABLE 1}

\section{Proposed terminology}

Two groups of entheses can be distinguished according to the tissue type present at the skeletal attachment site (Benjamin et al., 1986, 2002; Cooper and Misol, 1970; see Villotte et al., 2010b for a list of the main post-cranial fibrous and fibrocartilaginous entheses). A normal fibrocartilaginous enthesis (FCE) is smooth, well circumscribed and devoid of vascular foramina (Benjamin et al., 2002; Henderson, 2009; Henderson et al., 2015; Villotte, 2006, 2009; Villotte et al., 2010b); thus any alteration from this definition is considered an EC. For fibrous entheses, for which there is no clear definition of a "normal" aspect, we consider a theoretical smooth cortical surface as a base line (Henderson, 2009; Villotte, 2006, 2009). In the following text "fibrous entheses" refers only to fibrous tendon attachment sites, and not to sites where fleshy muscle fibers attach to the periosteum (e.g. the origin of tibialis anterior muscle).

We distinguished three main categories of EC: mineralized tissue formation, surface discontinuity, and complete loss of original morphology with subcategories where appropriate (Fig. 3). Note that the definition of EC does not include architectural variation (e.g. a more or less developed deltoid tuberosity, or "waving" of the surface itself).

\subsection{Mineralized tissue formation}


The morphological change exceeds the level of the original surface, from roughness of the surface to a clear structure of any size or shape.

\subsubsection{Diffuse and non-protruding formation}

Not clearly distinct from the surface of the enthesis. Two morphological subtypes are identified according to the enthesis type.

\subsubsection{Grained surface}

A textural change of a diffuse granular nature (similar to fine grained sandpaper, Henderson et al., 2015) at FCEs (Fig. 1a). The surface does not look as smooth as it is in unaltered FCEs, and it can feel roughened to the touch. Based on a picture of a histological section of such a change (Fig. 6-11 and 6-63 in Schultz, 2003), this granular texture is likely to be related to the mineralization of the uncalcified fibrocartilage. ${ }^{1}$ This type of change is mainly seen at the ischial and radial tuberosities.

\subsubsection{Diffuse cortical irregularity}

The area is rough to the touch due to diffuse tissue formation (Fig. 1b). The surface looks well remodeled (i.e. likely to be long standing). This is an extremely common feature at fibrous entheses and may be related to the direct attachment of tendon fibers to bone (Villotte and Knüsel 2013). It is also seen at the margin (Zone 1 in Henderson et al. 2013, see also Villotte, 2006) of FCEs, a region with little fibrocartilage.

\subsubsection{Isolated protrusion}

Identified as a clearly distinct protrusion from the surface of the enthesis.

\subsubsection{Enthesophyte}

A clear bony projection (Fig. 1c) mostly seen at the margin of FCEs. The height of the projection can be easily measured, tends to be greater in length than in width, and tapers towards the end. In histological studies, these spurs have been found to contain (and be surrounded by) calcified fibrocartilage from the original entheses (Abreu, et al.2003; Moriggl et al.2001; Rufai et al. 1995). Enthesophytes form through endochondral ossification in the Achilles tendon and subscapular ligament (Moriggl et al. 2001; Rufai et al. 1995), but they form through intramembranous and chondroidal ossification in the plantar fascia (Kumai and Benjamin 2002).

\subsubsection{Raised margin}

A raised rim at the margin of a FCEs (Fig. 1d) that is not as developed as an enthesophyte (i.e. it is difficult to measure the height of the bony projection).

\subsubsection{Longitudinal protrusion}

1 Or, as stated by Schultz (2003), related to the ossification of the tendon. However, this second hypothesis seems less likely. In the caption of the figure 6.63, Schultz (2003) stated that the two layers of calcified tissue (green structures) correspond to mineralized tendon and that the process occurred in two waves. Actually, it seems to correspond to the layers of uncalcified and calcified fibrocartilage separated by the tidemark (see Benjamin et al., 2002), the first layer being mineralized in that pathological case. 
A longitudinal bony protrusion at a fibrous enthesis normally affects nearly the entire length of the enthesis (Fig. 1e), either continuously or discontinuously. The protrusion is clearly distinct from the surrounding cortical surface, but it is not as developed and distinctive as an enthesophyte (i.e. it is difficult to measure the height of the bony projection). It can occur in conjunction with a smooth or a coarse surface.

\subsubsection{Shapeless protrusion}

A relatively flat or mound-like protruding mineralized tissue formation (Fig. 1f). It is highly variable in size, affecting a very limited part of the enthesis (a small raised area, i.e. nodule) to the entire attachment site. It occurs at both fibrocartilaginous (typically the central portion) and fibrous entheses.

\section{FIGURE 1}

\subsection{Surface discontinuity}

Depressions and other mineralized tissue loss of the surface (Rothschild, 2013). In fibrous entheses, cortical surface discontinuity can also involve the trabecular bone. In FCEs, the discontinuity involves the calcified cartilage and the subchondral bone (i.e. the subchondral bone plate and the trabecular bone). Possible origins include a resorptive process, a resorptive and hypertrophic process, hypervascularisation or avulsions (e.g. Flemming et al., 2003; Miller et al., 2004; Milz et al., 2004).

\subsubsection{Porosity}

Pores are macroscopically observable small rounded openings in the surface ${ }^{2}$.

\subsubsection{Fine porosity}

Very small pinholes with a diameter of less than $1 \mathrm{~mm}$, usually occurring in a cluster (Henderson et al. 2015). The opening is too small to see the subsurface morphology. These occur at both fibrocartilaginous and fibrous entheses (Fig. 2a).

\subsubsection{Macro porosity}

Pores $\geq 1 \mathrm{~mm}$ in diameter (Henderson et al. 2015), which occur singularly or in small clusters at fibrocartilaginous or fibrous entheses (Fig. 2b). The subsurface morphology is variable and, depending on the size of the opening, can sometimes be seen. When the subsurface morphology has the appearance of a channel, the pore is very likely a vascular foramen (often seen during skeletal development in FCEs). A macro pore can also be the entrance to a cavitation (see 2.2.3).

\subsubsection{Cortical defect}

2 We avoided the term "pitting", very often used as a descriptive term in paleopathology, but usually not defined (e.g. Ortner, 2003; Roger and Waldron, 2015). However, it should be noted that our definition of "porosity" is similar to the definition of "pitting" given by Waldron (2008:27) in the context of changes taking place in articulating bones: "pitting on the joint surface manifested as a series of holes on the joint surface, some of which may communicate with sub-chondral cysts." 
Focal bone loss, usually longitudinal in shape, often remodeled, and of variable depth (Fig. 2c). The floor of the depression often exhibits numerous pores. Cortical defects are mostly seen at the metaphyseal region of long bones, especially on the humerus at the insertions of the MM. pectoralis major and teres major, and at the attachment of the costoclavicular ligament on the clavicle. Possible origins include an avulsion, or an erosion from the periosteal or endosteal surface (Villotte, 2008). In immature skeletons, cortical defects at metaphyseal attachment sites are likely related to the unbalanced activity of osteoclasts and osteoblasts when the attachments of tendons and ligaments migrate as long bones grow in length (Villotte and Knüsel 2013).

\subsubsection{Erosive lesion}

Destruction of the mineralized cartilage and subchondral bone (Henderson et al. 2015). The erosive lesion is generally greater in width than depth. Its edges are often irregular and can be minimally or significantly remodeled. The floor of the depression exhibits exposed trabeculae or numerous pores (Fig. 2d). The morphology is very similar to erosions at synovial joints (see Rogers and Waldron, 1995:12). It can be observed at virtually all the appendicular FCEs.

\subsubsection{Cavitation}

Spherical subchondral lacuna with an opening at the surface that is smaller than the diameter of the cavitation and a clear floor that is not a channel (Henderson et al. 2015) (Fig. 2e). Usually cavitations have remodeled trabecular bone walls. They may correspond to the cysts described in the biomedical literature (Milz et al., 2004; Fritz et al., 2007). Cavitations are only seen at FCEs, especially at the proximal humerus.

\subsubsection{Furrowed surface (fibrous entheses)}

This feature seems to occur only at fibrous entheses in immature skeletons. The cortical surface is covered by very thin, straight furrows of variable length (usually no more than a 2-3 millimeters) that are generally oriented along the long axis of the attachment (Fig. 2f). The appearance of numerous areas of bone resorption interspersed with hypertrophic bone formation suggests the furrows are related to the active process of bone growth (Villotte and Knüsel, 2013).

\subsection{Complete loss of original morphology}

Associated with bone formation, and / or erosion, and porosity (Fig. 2g). Loss of morphology is most often seen at the greater tuberosity of the humerus.

\section{FIGURE 2}

\section{FIGURE 3}

TABLE 2

\section{Conclusion}



researchers evaluated these morphological changes it became clear that both the common name for them and the varied descriptive terminology lacked scientific rigor and consistency (Jurmain and Villotte, 2010), and our goal here is to propose an initial attempt towards greater standardization. In so doing, we hope to encourage further discussion and a more focused intellectual exchange among bioarcheologists and paleopathologists.

\section{Acknowledgements}

The authors would like to thank the Wenner-Gren Foundation (grant number Gr. CONF-632) for funding the workshop entitled 'EC and Reconstruction of Human Behavior: Towards Standardization' hosted by CIAS (Research Centre for Anthropology and Health, University of Coimbra, Portugal - UID/ANT/00283/2013) with support from CRIA (Centro em Rede de Investigação em Antropologia, Universidade de Nova, Lisbon, Portugal - UID/ANT/04038/2013). We also thank W. Reichmann, who took the pictures in Figures 1d and 2e together with D. Pany-Kucera at the 18th Paleopathology Association meeting in Vienna, Austria, with the permission of M. Teschler- Nicola. The copyright of those pictures is retained by the Natural History Museum Vienna, Austria. Fig. 2a has been taken by V. Mariotti at the Dpt. BiGEA of the Alma Mater Studiorum, University of Bologna, with permission of M. G. Belcastro. We are also grateful to the many colleagues who kindly participated in the survey concerning the terms they use for entheseal changes. We would like to thank Maria Alejandra Acosta (CEF-Centre for Functional Ecology and the Laboratory of Forensic Anthropology, University of Coimbra) for translating the terminology into Spanish. Finally, we would like to thank the three anonymous reviewers for their useful comments.

Authors C. Henderson and F. Alves Cardoso are funded by the Portuguese FCT - Fundação para a Ciência e a Tecnologia bursary SFRH/BPD82559/2011 and Investigator Programme IF/00127/2014, respectively and supported by the European Commission ESF and POPH.

\section{References}

Abreu, M.R., Chung, C.B., Mendes, L., Mohana-Borges, A., Trudell, D., Resnick, D., 2003. Plantar calcaneal enthesophytes: new observations regarding sites of origin based on radiographic, MR imaging, anatomic and palaeopathologic analysis. Skeletal Radiol. 32, 13-21.

Benjamin, M., Evans, E.J., Copp, L., 1986. The histology of tendon attachments to bone in man. J. Anat. 149, 89-100.

Benjamin, M., Kumai, T., Milz, S., Boszczyk, B.M., Boszczyk, A.A., Ralphs, J.R., 2002. The skeletal attachment of tendons - tendon "entheses."Comp. Biochem. Physiol. A Mol. Integr. Physiol. 133, 931-945.

Cooper, R.R., Misol, S., 1970. Tendon and ligament insertion. A light and electron microscopic study. J. Bone. Joint. Surg. Am. 52, 1-20.

Dutour, O., 1986. Enthesopathies (lesions of muscular insertions) as indicators of the activities of Neolithic Saharan populations. Am. J. Phys. Anthropol. 71, 221-224.

Flemming, D.J., Murphey, M.D., Shekitka, K.M., Temple, H.T., Jelinek, J.J., Kransdorf, M.J., 2003. Osseous involvement in calcific tendinitis: a retrospective review of 50 cases. Am. J. Roentgenol. 181, 965-972.

Fritz, L.B., Ouellette, H.A., O'Hanley, T.A., Kassarjian, A., Palmer, W.E., 2007. Cystic changes at supraspinatus and infraspinatus tendon insertion sites: association with age and rotator cuff disorders in 238 patients. Radiology 244, 239-248.

Havelková, P., Villotte, S., Velemínský, P., Poláček, L., Dobisíková, M., 2011. Enthesopathies and activity patterns in the Early Medieval Great Moravian population: Evidence of division of labour. Int. J. Osteoarchaeol. 21, 487-504. 
Havelková, P., Hladík, M., Velemínský, P., 2013. Entheseal changes: do they reflect socioeconomic status in the Early Medieval Central European population? (Mikulčice - Klášteřisko, Great Moravian Empire, 9th - 10th century). Int. J. Osteoarchaeol. 23, 237-251.

Hawkey, D.E., Merbs, C.F., 1995. Activity-induced musculoskeletal stress markers (MSM) and subsistence strategy changes among ancient Hudson Bay Eskimos. Int. J. Osteoarchaeol. 5, 324-338.

Henderson, C.Y., 2009. Musculo-skeletal stress markers in bioarchaeology: indicators of activity levels or human variation? A re-analysis and interpretation. $\mathrm{PhD}$ thesis. Department of Archaeology, Durham University.

Henderson, C.Y., Mariotti, V., Pany-Kucera, D., Villotte, S., Wilczak, C., 2013. Recording specific entheseal changes of fibrocartilaginous entheses: initial tests using the Coimbra Method. Int. J. Osteoarchaeol. 23, $152-162$.

Henderson, C.Y., Mariotti, V., Pany-Kucera, D., Villotte, S., Wilczak, C., 2015. The new “Coimbra method”: a biologically appropriate method for recording specific features of fibrocartilaginous entheseal changes. Int. J. Osteoarchaeol. [early view] DOI: 10.1002/oa.2477

Jurmain, R., Villotte, S., 2010. Terminology. Entheses in medical literature and physical anthropology: a brief review. Document published online in 4th February 2010 following the Workshop in Musculoskeletal Stress Markers (MSM): limitations and achievements in the reconstruction of past activity patterns, University of Coimbra, July 2-3, 2009. Coimbra, CIAS - Centro de Investigação em Antropologia e Saúde. Consulted in 27th February 2015. Available from: http://www.uc.pt/en/cia/msm/MSM_terminology3.pdf.

Kumai, T., Benjamin, M., 2002. Heel spur formation and the subcalcaneal enthesis of the plantar fascia. J Rheumatol. 29, 1957-1964.

Lieverse, A.R., Bazaliiskii, V.I., Goriunova, O.I., Weber, A.W., 2013. Lower limb activity in the Cis-Baikal: Entheseal changes among middle Holocene Siberian foragers. Am. J. Phys. Anthropol. 150, 421-432.

Mariotti, V., Facchini, F., Belcastro, M.G., 2004. Enthesopathies - Proposal of a standardized scoring method and applications. Coll. Antropol. 28, 145-159.

Mariotti, V., Facchini, F., Belcastro, M.G., 2007. The Study of Entheses: Proposal of a Standardized Scoring Method for Twenty-Three Entheses of the Postcranial Skeleton. Coll. Antropol. 31, 291-313.

Moriggl, B., Jax, P., Milz, S., Buttner, A., Benjamin, M., 2001. Fibrocartilage at the entheses of the suprascapular (superior transverse scapular) ligament of man - a ligament spanning two regions of a single bone. J. Anat. 199: 539-545

Miller, T.T., Adler, R.S., Friedman, L., 2004. Sonography of injury of the ulnar collateral ligament of the elbowinitial experience. Skeletal Radiol. 33, 386-391.

Milz, S., Tischer, T., Buettner, A., Schieker, M., Maier, M., Redman, S., Emery, P., McGonagle, D., Benjamin, M., 2004. Molecular composition and pathology of entheses on the medial and lateral epicondyles of the humerus: a structural basis for epicondylitis. Ann. Rheum. Dis. 63, 1015-1021.

Ortner, D., 2003. Identification of Pathological conditions in human skeletal remains. Second Edition. Academic Press, Amsterdam.

Robb, J.E., 1998. The interpretation of skeletal muscle sites: a statistical approach. Int. J. Osteoarchaeol. 8, 363377.

Rogers, J., Waldron, T., 1995. A field guide to joint disease in archaeology. John Wiley \& Sons, Chichester.

Rothschild, B.M., 2013. Nondestructive, epi-illumination surface microscopic characterization of surface discontinuity in bone: A new approach offers a descriptive vocabulary and new insights. Anat. Rec. 296, 580589.

Rufai, A., Ralphs, J.R., Benjamin, M., 1995. Structure and histopathology of the insertional region of the human Achilles tendon. J. Orthop. Res. 13: 585-593

Santos, A.L., Alves Cardoso, F., Assis, S., Villotte, S., 2011. The Coimbra Workshop in Musculoskeletal Stress Markers (MSM): an annotated review. Antropologia Portuguesa 28, 135-161.

Schultz, M., 2003. Light microscopic analysis in skeletal paleopathology, in: Ortner, D. (Ed.), Identification of Pathological conditions in human skeletal remains. Second Edition. Academic Press, Amsterdam, pp. 73-108. 
Villotte, S., 2006. Connaissances médicales actuelles, cotation des enthésopathies: nouvelle méthode. Bull. Mem. Soc. Anthropol. Paris 18, 65-85.

Villotte, S., 2008. L’insertion humérale « en fosse » du muscle grand pectoral, in: Charlier, P. (Ed.), Ostéoarchéologie et techniques médico-légales: tendances et perspectives. Pour un "Manuel pratique de paléopathologie humaine". Editions De Boccard, Paris, pp. 391-392.

Villotte, S., 2009. Enthésopathies et activités des Hommes préhistoriques - Recherche méthodologique et application aux fossiles européens du Paléolithique supérieur et du Mésolithique. Archaeopress, Oxford.

Villotte, S., Churchill, S.E., Dutour, O., Henry-Gambier, D., 2010a. Subsistence activities and the sexual division of labor in the European Upper Paleolithic and Mesolithic: evidence from upper limb enthesopathies. J. Hum. Evol. 59, 35-43.

Villotte, S., Castex. D,, Couallier, V., Dutour, O., Knüsel C.J., Henry-Gambier, D., 2010b. Enthesopathies as occupational stress markers: evidence from the upper limb. Am. J. Phys. Anthropol. 142, 224-234.

Villotte, S., Knüsel, C.J., 2013. Understanding entheseal changes: definition and life course changes. Int. J. Osteoarchaeol. 23, 135-146.

Villotte, S., Knüsel, C.J., 2014. "I sing of arms and of a man...": medial epicondylosis and the sexual division of labour in prehistoric Europe. J. Archaeol. Sci. 43, 168-174.

Waldron, T., 2008. Palaeopathology. Cambridge University Press, Cambridge.

Table list

Table 1. Results of a survey eliciting responses on the naming of EC, specifically what is defined in this paper as an enthesophyte (Fig 1c white arrow).

Table 2. The proposed new terminology alongside translations into French, Italian, Portuguese, Spanish, and German. References to other illustrations in publications by the authors of the EC defined here are also provided.

Figure list

Figure 1. Examples of entheseal changes (mineralized tissue formation) to illustrate the terminology. a) grained surface. b) diffuse cortical irregularity. c) enthesophyte. d) raised margin. e) longitudinal protrusion. f) shapeless protrusion. Scale: $2 \mathrm{~cm}$.Photo credits: Villotte, S. (a, c, e, f); Assis, S. (b); Reichmann, W. and PanyKucera, D. (d).

Figure 2. Examples of entheseal changes (surface discontinuity, and complete loss of original morphology) to illustrate the terminology. a) fine porosity. b) macro porosity. c) cortical defect. d) erosive lesion. e) cavitation. f) furrowed surface. g) complete loss of original morphology. Scale: $2 \mathrm{~cm}$. Photo credits: Mariotti, V. (a); Villotte, S. (b, c, f, g); Henderson, C. (d); Reichmann, W. and Pany-Kucera, D. (e).

Figure 3. Graphical summary of the proposed terminology. "Fibrous"; fibrous entheses, "FC"; fibrocartilaginous entheses. 


\section{Click here to download high resolution image}
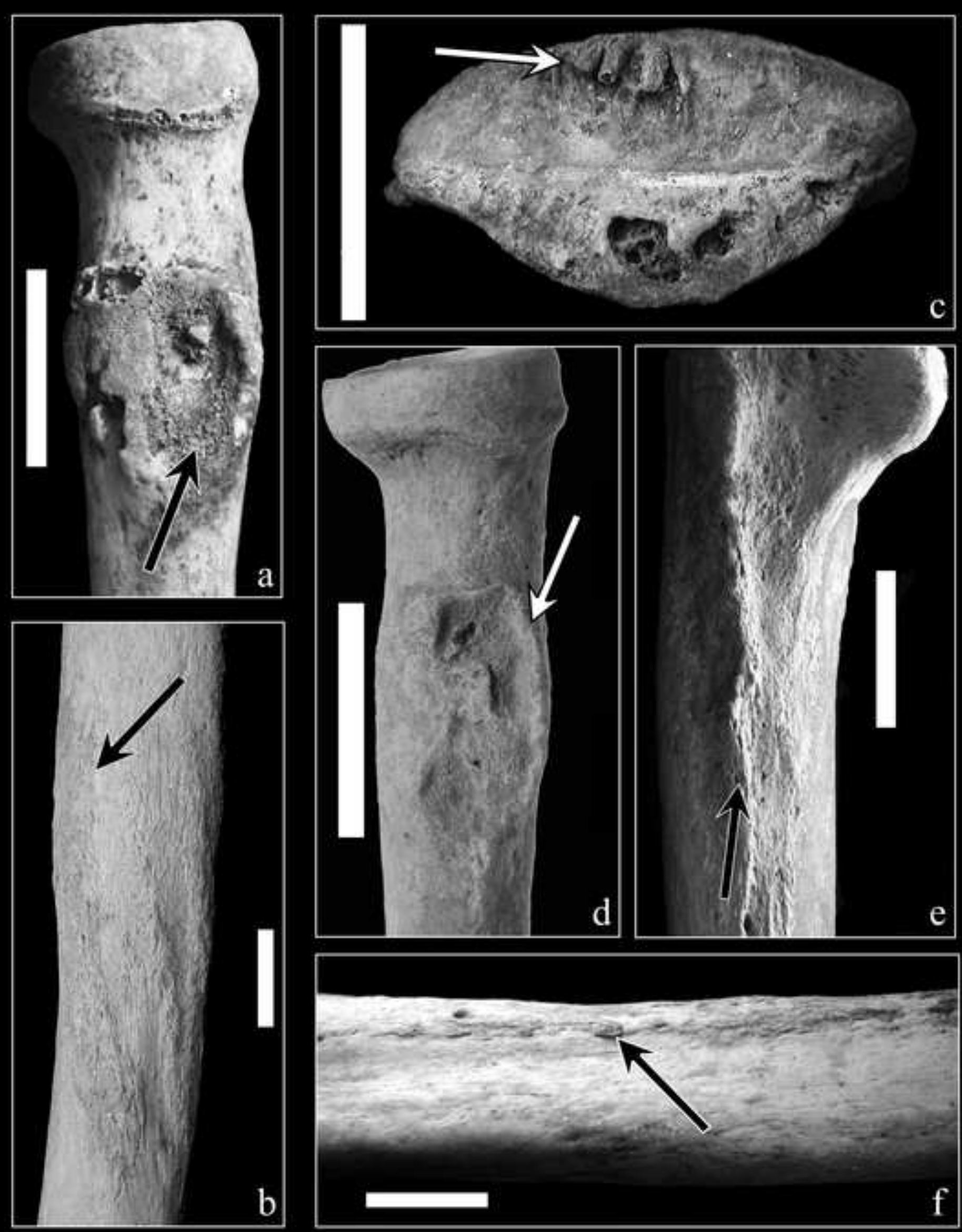
Click here to download high resolution image
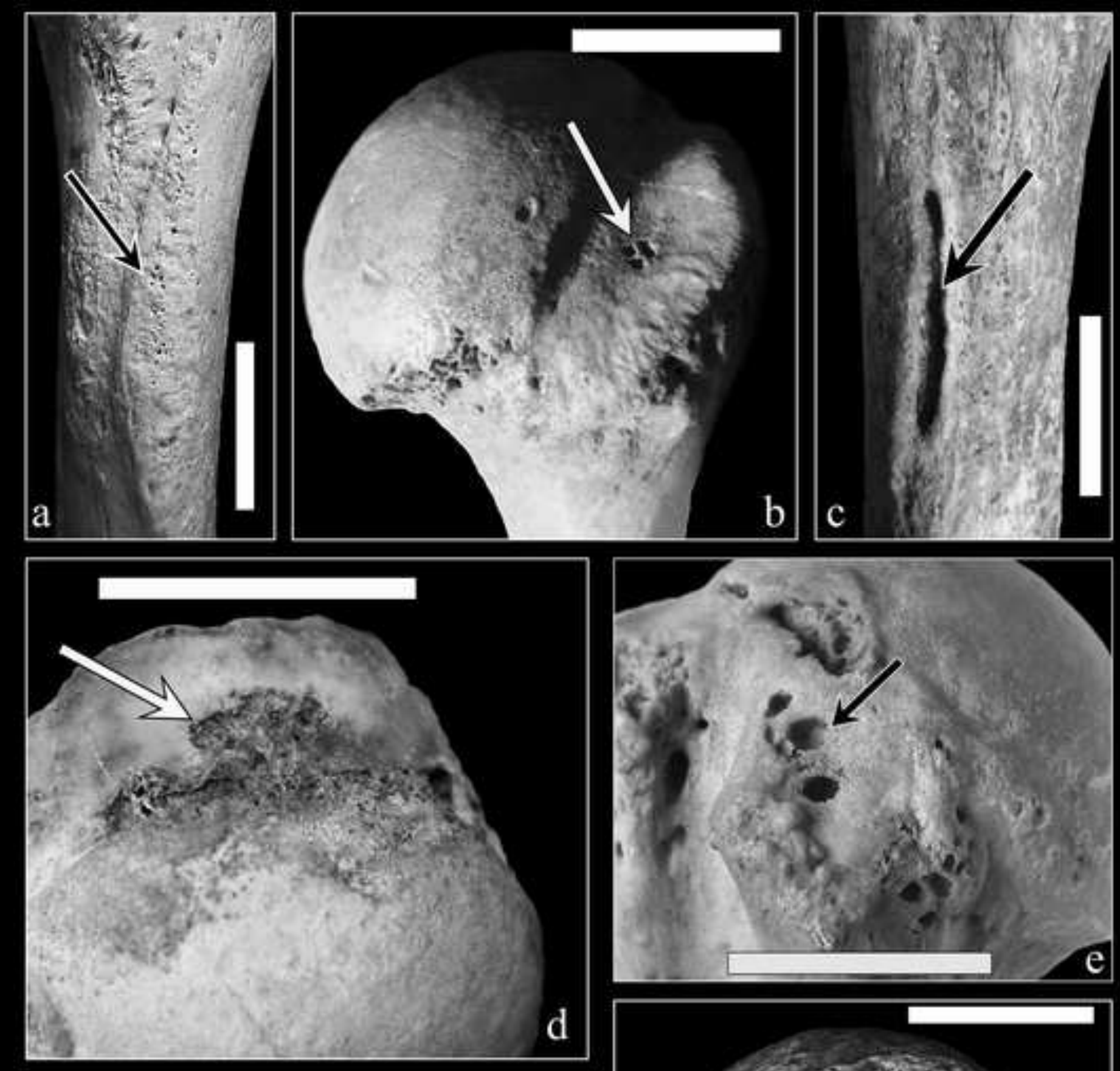

b



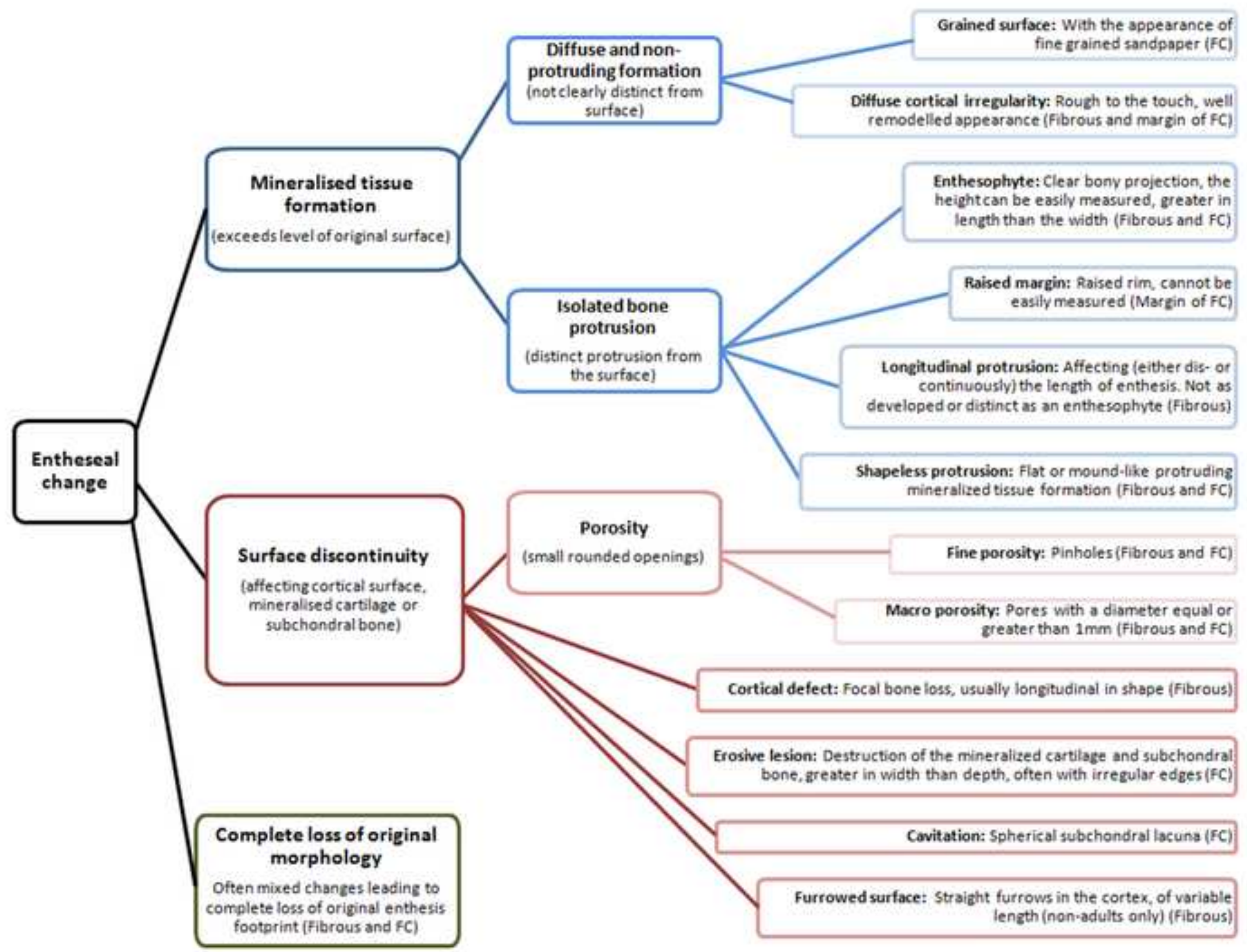


Table 1.

\begin{tabular}{lr}
\hline Answers & N \\
\hline \hline Enthesophyte(s) & 13 \\
Osteophyte(s) & 5 \\
Exostosis / exostoses & 4 \\
Bone spur(s) & 2 \\
Bone growth(s) / outgrowth(s) & 2 \\
EC & 2 \\
Bone formation & 1 \\
Enthesitis & 1 \\
Hyperostotic change(s) & 1 \\
Osteophytic formation & 1 \\
Total & 32 \\
\hline
\end{tabular}

$\frac{N}{13}$ 
Table 2

\begin{tabular}{|c|c|c|c|c|c|c|}
\hline Term & French & Italian & Portuguese & Spanish & German & $\begin{array}{l}\text { Illustrations in previous } \\
\text { papers by the authors }\end{array}$ \\
\hline $\begin{array}{l}\text { 1. Mineralised tissue } \\
\text { formation }\end{array}$ & $\begin{array}{l}\text { Formation de tissu } \\
\text { minéralisé }\end{array}$ & $\begin{array}{l}\text { Formazione di tessuto } \\
\text { mineralizzato }\end{array}$ & $\begin{array}{l}\text { Formação de tecido } \\
\text { mineralizado }\end{array}$ & $\begin{array}{l}\text { Formación de tejido } \\
\text { mineralizado }\end{array}$ & $\begin{array}{l}\text { Bildung von mineralisiertem } \\
\text { Knochengewebe }\end{array}$ & \\
\hline $\begin{array}{l}\text { 1.1. Diffuse and non- } \\
\text { protruding formation }\end{array}$ & $\begin{array}{l}\text { Formation diffuse et } \\
\text { non saillante }\end{array}$ & $\begin{array}{l}\text { Formazione diffusa e } \\
\text { non sporgente }\end{array}$ & $\begin{array}{l}\text { Formação difusa e não } \\
\text { protrusa }\end{array}$ & $\begin{array}{l}\text { Formación difusa y no } \\
\text { saliente }\end{array}$ & $\begin{array}{l}\text { Ausbildung diffuser und } \\
\text { nicht-erhabener Struktur }\end{array}$ & \\
\hline 1.1.1. Grained surface & $\begin{array}{l}\text { Surface rapeuse / } \\
\text { granuleuse }\end{array}$ & Superficie granulare & Superfície granular & Superficie granular & körnige Oberfläche & $\begin{array}{l}\text { Fig. 3a in } \\
\text { Henderson et al., } 2015\end{array}$ \\
\hline $\begin{array}{l}\text { 1.1.2. Diffuse cortical } \\
\text { irregularity }\end{array}$ & $\begin{array}{l}\text { Irregularité corticale } \\
\text { diffuse }\end{array}$ & $\begin{array}{l}\text { Irregolarità corticale } \\
\text { diffusa }\end{array}$ & $\begin{array}{l}\text { Irregularidade cortical } \\
\text { difusa }\end{array}$ & $\begin{array}{l}\text { Irregularidad cortical } \\
\text { difusa }\end{array}$ & $\begin{array}{l}\text { diffuse kortikale } \\
\text { Unregelmäßigkeit }\end{array}$ & $\begin{array}{l}\text { Fig. 1e and 5c in Villotte } \\
2006\end{array}$ \\
\hline $\begin{array}{l}\text { 2. Isolated bone } \\
\text { protrusion }\end{array}$ & $\begin{array}{l}\text { Projection osseuse } \\
\text { isolée }\end{array}$ & $\begin{array}{l}\text { Protrusione (o } \\
\text { escrescenza) ossea } \\
\text { isolata }\end{array}$ & $\begin{array}{l}\text { Protrusão óssea } \\
\text { isolada }\end{array}$ & $\begin{array}{l}\text { Protuberancia ósea } \\
\text { aislada }\end{array}$ & isolierter Knochenvorsprung & \\
\hline 2.1. Enthesophyte & Enthésophyte & Entesofita & Entesófito & Entesofito & Enthesiophyt & $\begin{array}{l}\text { Fig. 3b in Villotte 2006; } \\
\text { Fig. 2-4 in Mariotti et al., } \\
2004\end{array}$ \\
\hline 2.2. Raised margin & Marge saillante & Margine rialzato & Margem saliente & Margen saliente & erhöhter Rand & Fig. 1c in Villotte 2006 \\
\hline $\begin{array}{l}\text { 2.3. Longitudinal } \\
\text { protrusion }\end{array}$ & Saillie longitudinale & Cresta longitudinale & Protrusão longitudinal & $\begin{array}{l}\text { Protuberancia } \\
\text { longitudinal }\end{array}$ & $\begin{array}{l}\text { longitudinaler } \\
\text { Knochenvorsprung }\end{array}$ & $\begin{array}{l}\text { Fig. } 5 \mathrm{~g} \text { in Villotte 2006; } \\
\text { Fig. } 18,19,23 \text { in Mariotti } \\
\text { et al., } 2007\end{array}$ \\
\hline 2.4. Shapeless protrusion & Saillie amorphe & $\begin{array}{l}\text { Protrusione (o } \\
\text { escrescenza) amorfa }\end{array}$ & Protrusão amorfa & Protuberancia amorfa & formloser Knochenvorsprung & $\begin{array}{l}\text { Fig. } 6 \text { in Mariotti et al., } \\
2004\end{array}$ \\
\hline 3. Surface discontinuity & $\begin{array}{l}\text { Solution de continuité } \\
\text { de la surface }\end{array}$ & $\begin{array}{l}\text { Superficie } \\
\text { discontinua/discontinu } \\
\text { ità della superficie }\end{array}$ & $\begin{array}{l}\text { Discontinuidade na } \\
\text { superfíce }\end{array}$ & $\begin{array}{l}\text { Discontinuidad en la } \\
\text { superficie }\end{array}$ & Oberflächendiskontinuität & \\
\hline 3.1. Porosity & Porosité & Porosità & Porosidade & Porosidad & Porosität & $\begin{array}{l}\text { Fig. 4a in } \\
\text { Henderson et al., } 2015\end{array}$ \\
\hline 3.1.1. Fine porosity & Porosité fine & Porosità fine & Porosidade fina & Porosidad fina & Feinporosität & Fig. 2b in Villotte 2006 \\
\hline 3.1.2. Macro porosity & Macro porosité & Macroporosità & Macroporosidade & Macro porosidad & Makroporosität & $\begin{array}{l}\text { Fig. 3c in } \\
\text { Henderson et al., } 2015\end{array}$ \\
\hline 3.2. Cortical defect & Défaut cortical & Difetto corticale & Defeito cortical & Defecto cortical & kortikaler Defekt & $\begin{array}{l}\text { Fig. } 5 \mathrm{i} \text { in Villotte 2006; } \\
\text { Fig. } 11 \text { and } 14 \text { in Mariotti } \\
\text { et al., } 2004\end{array}$ \\
\hline 3.3. Erosive lesion & Lésion érosive & $\begin{array}{l}\text { Lesione erosiva / } \\
\text { erosione }\end{array}$ & Lesão erosiva & Lesión erosiva & erosive Läsion & Fig. $3 c$ in Villotte 2006 \\
\hline
\end{tabular}




\begin{tabular}{|c|c|c|c|c|c|c|}
\hline 3.4. Cavitation & Géode & Cavitazione & Cavitação & Cavitación & Hohlraum & $\begin{array}{l}\text { Fig. } 2 \mathrm{~b} \text { and } 5 \text { in } \\
\text { Henderson et al., } 2015\end{array}$ \\
\hline 3.5. Furrowed surface & $\begin{array}{l}\text { Surface couverte de } \\
\text { sillons }\end{array}$ & Superficie solcata & Superfície sulcada & Superficie surcada & geriffelte Oberfläche & $\begin{array}{l}\text { Fig. } 5 \text { in Villotte and } \\
\text { Knüsel } 2013\end{array}$ \\
\hline $\begin{array}{l}\text { 4. Complete loss of } \\
\text { original morphology }\end{array}$ & $\begin{array}{l}\text { Perte complete de la } \\
\text { morphologie originale }\end{array}$ & $\begin{array}{l}\text { Perdita della } \\
\text { morfologia originale }\end{array}$ & $\begin{array}{l}\text { Perda completa da } \\
\text { morfologia original }\end{array}$ & $\begin{array}{l}\text { Perdida completa de la } \\
\text { morfología original }\end{array}$ & $\begin{array}{l}\text { vollständiger Verlust der } \\
\text { ursprünglichen Morphologie }\end{array}$ & \\
\hline
\end{tabular}

